\title{
Ontogeny of Substance P Receptor Binding Sites in Rat Brain
}

\author{
Rémi Quirion and Than-Vinh Dam \\ Douglas Hospital Research Centre and Department of Psychiatry, Faculty of Medicine, McGill University, Verdun, \\ Québec H4H 1R3, Canada
}

\begin{abstract}
The ontogeny of substance $P$ (SP) receptor binding sites in rat brain has been studied using both membrane binding assays and in vitro receptor autoradiography. The density of SP binding sites is maximal $1 \mathrm{~d}$ before birth and decreases thereafter to reach adult values $14 \mathrm{~d}$ after birth. During the early postnatal period, the distribution of SP binding sites undergoes major modifications. For example, very high densities of SP binding sites are present in most brain stem nuclei from 1 to $14 \mathrm{~d}$ after birth, while it is not the case in adults. In the striatum, SP receptors are distributed in a "patchy" manner early after birth, while it is much more homogenous in the adult. This demonstrates that SP receptors undergo major redistributions during postnatal development. The very high density of SP binding sites present in the brain at its early stages of development may indicate that SP could be an important factor involved in the early organization of the CNS.
\end{abstract}

More than 50 years ago, Von Euler and Gaddum (1931) reported on the presence of an unidentified depressor factor in brain and gut that they named substance $P$ (SP). Later on, Chang and Leeman (1970) purified SP to homogeneity and demonstrated that is was an undecapeptide member of the tachykinin family (Erspamer, 1981). Since then, multiple radioimmunological and immunohistochemical studies have described the extensive distribution of SP-like materials in mammalian brain (Brownstein et al., 1976; Cuello and Kanazawa, 1978; Ljungdahl et al., 1978; Shults et al., 1984). High concentrations of SP-like immunoreactivity are found in various brain regions-including the striatum, the hypothalamus, the substantia nigra, and the superficial layers of the dorsal horn of the spinal cord-suggesting possible roles for SP in various brain functions (Pernow, 1983).

Moreover, the distribution of SP receptor binding sites in CNS and PNS also suggests important roles for SP and related peptides in the integration of brain functions (Charlton and Helke, 1985; Helke et al., 1984; Mantyh et al., 1984a; Mohini et al., 1985; Quirion, 1985; Quirion and Dam, 1985a; Quirion et al., 1983; Rothman et al., 1984; Shults et al., 1984; Wolf et al., 1985). For example, the high densities of SP receptors in olfactory, visual, auditory, and pain pathways suggest that SP is probably involved in the control of sensory processes (Quirion et al., 1983). Moreover, the presence of dense SP-receptor populations in hippocampus and certain cortical areas indicates that SP might be involved in the mediation of cognitive functions (Quirion and Dam, 1985b; Quirion et al., 1983).

Various functional studies also reveal the possible extensive role of SP in the brain (Pernow, 1983). In particular, it has been

\footnotetext{
Received Sept. 20, 1985; revised Jan. 9, 1986; accepted Feb. 20, 1986.

This work was supported by an Establishment Grant from the Fonds de la Recherche en Santé du Québec (FRSQ). R. Quirion is a Chercheur-Boursier of the FRSQ. We are grateful to Joan Currie for preparation of the manuscript.

Correspondence should be addressed to Dr. Rémi Quirion, Douglas Hospital Research Centre, 6875 LaSalle Blvd., Verdun, Québec H4H 1R3, Canada.

Copyright (C) 1986 Society for Neuroscience $0270-6474 / 86 / 082187-13 \$ 02.00 / 0$
}

shown that SP is released from the terminals of certain primary afferent neurons following nervous stimuli (Otsuka and Konishi, 1983). The released SP could then induce an excitatory effect on spinal dorsal horn neurons (Henry, 1976) that would generate a painful stimuli (Otsuka and Konishi, 1983). Moreover, intrathecal injections of SP elicit behavioral effects suggestive of pain sensation (Hylden and Wilcox, 1981) and SP receptor blockers have analgesic actions when applied intrathecally (Rosell and Folkers, 1982). Thus, it has been suggested that SP should be considered as the first peptide neurotransmitter (Otsuka and Konishi, 1983).

However, very little is currently known on the developmental aspects of SP and its receptors in the CNS, even if it has been shown that SP stimulates neurite outgrowth (Narumi and Fujita, 1978; Narumi and Maki, 1978), counteracts neurotoxin-induced damage or norepinephrine and 5-HT neurons during ontogeny (Jonsson and Hallman, 1982a, b, 1983a, b; Nakai and Kasamatsu, 1984), and activates connective tissue cell growth (Nilsson et al., 1985). A few recent studies have demonstrated the early prenatal appearance of SP brain pathways (Charnay et al., 1983; Del Fiacco et al., 1984; Inagaki et al., 1982; Kessler and Black, 1981; McGregor et al., 1982; Namura et al., 1982; Paulin et al., 1980; Sakanaka et al., 1982), while the development of SP receptors is totally unknown. We report here on the ontogeny of SP receptor binding sites in rat brain using membrane binding assays and in vitro receptor autoradiography. Our data demonstrate that the distribution of SP receptors undergoes major redistribution during postnatal ontogeny, suggesting important roles for SP during brain development.

\section{Materials and Methods}

\section{Animals and chemicals}

Timed-pregnant Sprague-Dawley female rats were obtained from $\mathrm{Ca}$ nadian Breeding Farms (St. Constant, Québec). Animals were individually housed in polyethylene cages, maintained on a $12 \mathrm{hr}$ light-dark cycle, and given free access to food and water. After birth, pups were kept with their mothers until weaning, if applicable. Synthetic SP was purchased from Peninsula Laboratories (San Carlos, CA). Radiolabeled monoiodinated Bolton-Hunter SP ( ${ }^{125} \mathrm{I}-\mathrm{BH}-\mathrm{SP} ; 2000 \mathrm{Ci} / \mathrm{mmol}$ ) was obtained from New England Nuclear (Boston, MA). Trisma, BSA, bacitracin, leupeptin, chymostatin, EDTA, and manganese chloride were obtained from Sigma Chemical Company (St. Louis, MO). Other chemicals were obtained from usual commercial sources.

\section{Cell membrane preparations}

For experiments using prenatal rats, timed-pregnant female rats were killed by decapitation on the appropriate day and prenatal pups ( 1 and $3 \mathrm{~d}$ before birth, E17, E20) were decapitated; their brains were rapidly isolated and snap-frozen in 2 -methylbutane at $40^{\circ} \mathrm{C}$. For postnatal experiments, animals of either sex were selected at random from different litters at various ages ( $1 \mathrm{~d}$ to 3 months after birth) and decapitated, and their brains were snap-frozen as described above.

Cell membranes were prepared as follows: Brains were homogenized in 10 vol of $50 \mathrm{~mm}$ Tris $\mathrm{HCl}$ buffer, $\mathrm{pH} 7.4$, at $4^{\circ} \mathrm{C}$ plus $120 \mathrm{~mm} \mathrm{NaCl}$ and $5 \mathrm{~mm} \mathrm{KCl}$ using a Brinkmann polytron (setting $6,20 \mathrm{sec}$ ). The 
Table 1. Relative potency of various substance P-related peptides and analogs in competing for brain ${ }^{125}$ I-BH-SP binding sites during ontogeny

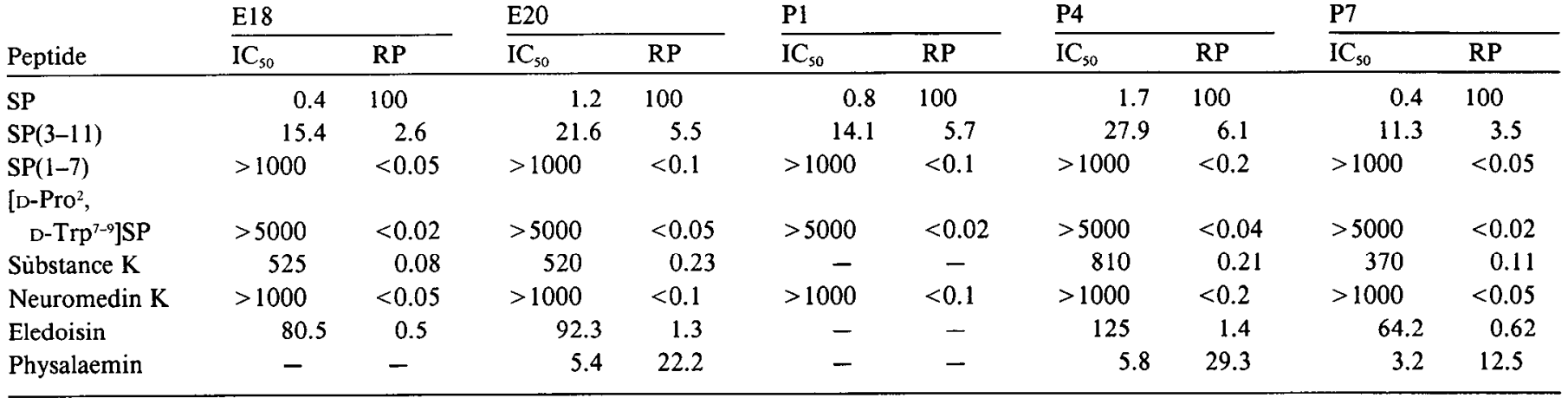

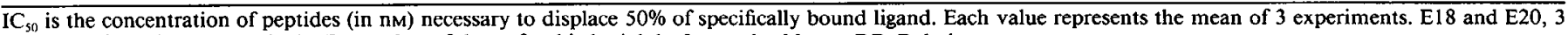
and $1 \mathrm{~d}$ before birth, respectively; $\mathrm{P}$, number of days after birth; Adult, 3-month-old rats. RP, Relative potency.

homogenate was then centrifuged for $10 \mathrm{~min}$ at $50,000 \times \mathrm{g}$. The supernatant was discarded and the pellet resuspended in $50 \mathrm{mM}$ Tris $\mathrm{HCl}$ buffer, pH 7.4 , at $4^{\circ} \mathrm{C}$ plus $300 \mathrm{~mm} \mathrm{KCl}$ and $10 \mathrm{~mm}$ EDTA $\cdot \mathrm{K}_{2}$ before incubation on ice for $30 \mathrm{~min}$ with gentle agitation. After centrifugation as above, the pellet was resuspended in 20 vol of $50 \mathrm{~mm}$ Tris $\mathrm{HCl}$ buffer, pH 7.4 , at $4^{\circ} \mathrm{C}$ and recentrifuged at $50,000 \times g$ and the supernatant discarded. The pellet was washed twice with $50 \mathrm{~mm}$ Tris $\mathrm{HCl}$ buffer, pH 7.4 , at $4^{\circ} \mathrm{C}$ before final resuspension in $60 \mathrm{vol}$ of the same buffer. Aliquots were taken for protein determination (Lowry et al., 1951).

For binding assays, $200 \mu \mathrm{l}$ of membrane suspension werc incubated

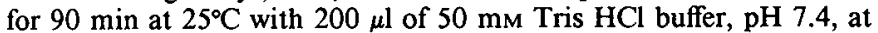
room temperature containing $3 \mathrm{mM} \mathrm{MnCl}_{2}, 0.02 \% \mathrm{BSA}, 2 \mu \mathrm{g} / \mathrm{ml}$ chymostatin, $4 \mu \mathrm{g} / \mathrm{ml}$ leupeptin, $40 \mu \mathrm{g} / \mathrm{ml}$ bacitracin, and various concentrations of ${ }^{125} \mathrm{I}-\mathrm{BH}-\mathrm{SP}$. Incubations were terminated by rapid filtration (Cell Harvester M-24R, Brandel Co., Gaithersburg, MD) and three 3 $\mathrm{ml}$ washes with cold buffer through Whatman GF/C filter strips presoaked in $0.1 \%$ polyethyleneimine for at least $3 \mathrm{hr}$ prior to filtration. Specific binding was calculated as the difference in radioactivity bound in presence and absence of $1 \mu \mathrm{M}$ SP. Binding of the ligand to filters was quantitated by counting filters with an LKB gamma counter with 80 $85 \%$ efficiency. Under these conditions, specifically bound ${ }^{125}$ I-SP represent $75-80 \%$ of the bound ligand at half $K_{d}$ values.

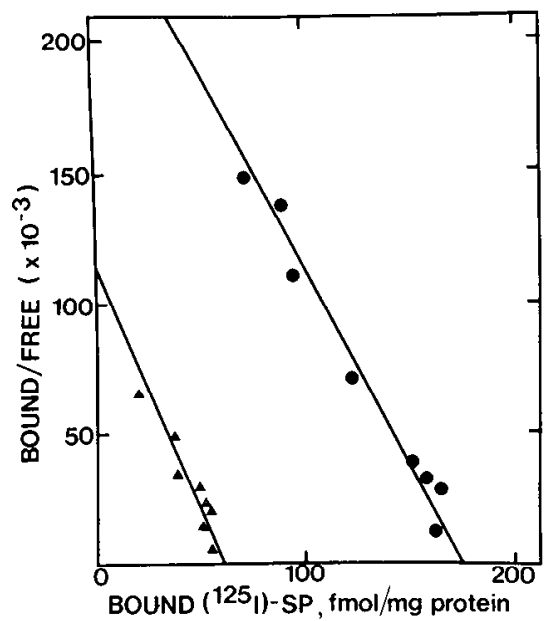

Figure 1. Specific binding of ${ }^{125}$ I-BH-SP to rat brain membrane preparations during ontogeny expressed as a Scatchard analysis. Typical data at E20 ( ()$, 1 \mathrm{~d}$ before birth, and P21 (A), $21 \mathrm{~d}$ after birth are shown. Specific binding of SP to rat brain membrane preparations has been investigated as described in Materials and Methods. Data are means of 3 experiments that varied less than $15 \%$ among one another. Respective $K_{\mathrm{d}}$ values at E20 and $\mathrm{P} 21$ are 0.7 and $0.6 \mathrm{nM}$, while $B_{\max }$ values are 177 and $62 \mathrm{fmol} / \mathrm{mg}$ protein, respectively.

\section{Autoradiographic procedure}

For autoradiography, postnatal rat brain sections were prepared as described before (Herkenham and Pert, 1982; Quirion et al., 1981, 1983; Unnerstall et al., 1981). Briefly, animals were killed by decapitation, and their brains were rapidly isolated and immersed in 2-methylbutane at $-40^{\circ} \mathrm{C}$, mounted on cryostat chucks, and cut into $25-\mu$ m-thick sections at $-18^{\circ} \mathrm{C}$. Sections were thaw-mounted near the edge of precleaned gelatin-coated slides, air-dried on ice for $2 \mathrm{hr}$, and then stored at $-80^{\circ} \mathrm{C}$ until used. Frozen slide-mounted brain sections were incubated for 90 min as described above for cell membrane binding assays and in presence of $50 \mathrm{pm}{ }^{125} \mathrm{I}-\mathrm{BH}-\mathrm{SP}$. At the end of the incubation, slides were placed in racks and transferred sequentially through 4 rinses (1 min each) of $50 \mathrm{~mm}$ Tris $\mathrm{HCl}, \mathrm{pH} \mathrm{7.4}$, at $4^{\circ} \mathrm{C}$. Specific binding of SP was defined as described above for membrane binding assays. Incubated slides were then rapidly dried under a stream of cold air and juxtaposed tightly against tritium-sensitive film (Ultrofilm, LKB) and stored at room temperature for 12-15 d. After this exposure, films were developed and processed as described before (Herkenham and Pert, 1982; Quirion et al., 1981).

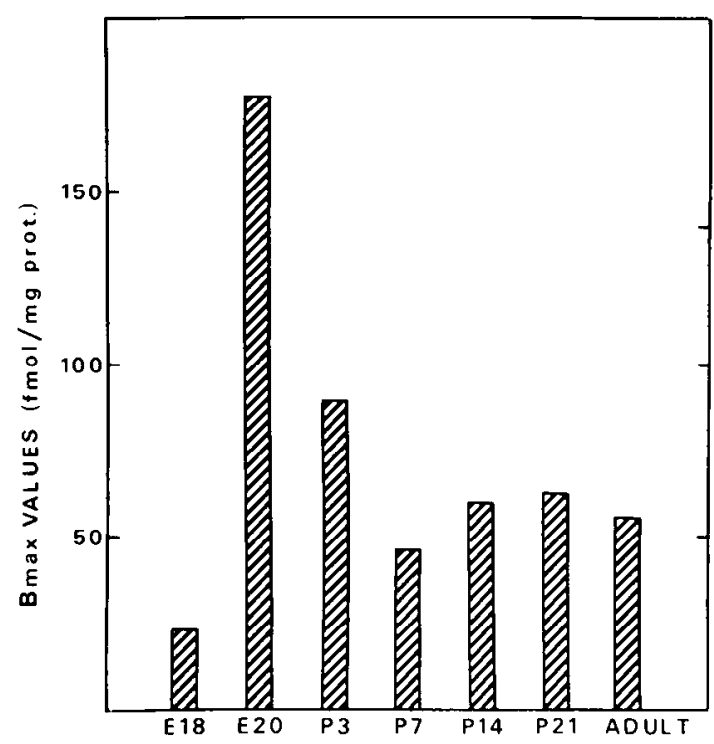

Figure 2. Maximal number $\left(B_{\max }\right)$ of SP binding sites present in rat brain membranes during ontogeny. Specific binding of SP to rat brain membrane preparations has been investigated as described in Materials and Methods. Data are means of 3 experiments that varied less than $15 \%$ among each other. E18 and E20, mean 3 and $1 \mathrm{~d}$ before birth, respectively; $P$, number of days postnatally; adult, 3-month-old rats. 


\begin{tabular}{|c|c|c|c|c|c|}
\hline \multicolumn{2}{|l|}{ P14 } & \multicolumn{2}{|l|}{ P21 } & \multicolumn{2}{|l|}{ Adult } \\
\hline $\mathrm{IC}_{50}$ & RP & $\mathrm{IC}_{50}$ & $\mathrm{RP}$ & $\mathrm{IC}_{50}$ & RP \\
\hline 0.4 & 100 & 0.2 & 100 & 0.4 & 100 \\
\hline 14.9 & 2.3 & 12.4 & 1.7 & 16.0 & 2.5 \\
\hline$>1000$ & $<0.05$ & $>1000$ & $<0.05$ & $>1000$ & $<0.05$ \\
\hline$>5000$ & $<0.02$ & $>5000$ & $<0.02$ & $>5000$ & $<0.02$ \\
\hline 230 & 0.18 & 380 & 0.05 & 470 & 0.09 \\
\hline$>1000$ & $<0.05$ & $>1000$ & $<0.05$ & $>1000$ & $<0.05$ \\
\hline 86.1 & 0.46 & 92.4 & 0.22 & 83.9 & 0.48 \\
\hline 3.5 & 11.4 & 2.5 & 8.0 & 3.2 & 12.5 \\
\hline
\end{tabular}

\section{Results}

\section{Membrane binding assays}

The maximal number of specific SP binding sites markedly varies during pre- and postnatal ontogeny (Figs. 1, 2). Typical Scatchard analysis data are represented in Figure 1. As shown in this figure, the maximal number of sites $\left(B_{\max }\right)$ is very high $1 \mathrm{~d}$ before birth $(177 \mathrm{fmol} / \mathrm{mg}$ protein), while it is much lower $21 \mathrm{~d}$ after birth $(62 \mathrm{fmol} / \mathrm{mg}$ protein). However, the affinitics $\left(K_{\mathrm{d}}\right)$ do not change significantly during this period $(0.7$ vs 0.6 nM at E20 and P21, respectively).

Globally, a marked increase in the number of SP binding sites is observed just before birth with a 5 times increase in $B_{\max }$ values from E18 to E20 (Fig. 2). Three days after birth, only half of the SP binding sites found at E20 are still present (Fig. 2). The lowest density of SP sites is observed at P7 and subsequently reaches adult levels at P14 (Fig. 2). $K_{\mathrm{d}}$ values did not markedly change during ontogeny, with values being $0.8,0.7$, $1.0,0.4,0.5,0.6$, and $0.6 \mathrm{~nm}$ for E18, E20, P3, P7, P14, P21, and adult, respectively.

The ligand selectivity pattern suggests that ${ }^{125} \mathrm{I}-\mathrm{BH}-\mathrm{SP}$ binds to a similar class of sites during ontogeny. As shown in Table 1, SP and physalaemin, an SP homolog (Wolf et al., 1985) are potent displacers of ${ }^{125}$ I-BH-SP binding throughout brain development, while SP fragments such as SP(3-11) and SP(1-7) are much weaker. Other mammalian tachykinins that are likely to interact with different receptors (Quirion, 1985), such as substance $\mathrm{K}$ and neuromedin $\mathrm{K}$, are very weak displacers of ${ }^{125} \mathrm{I}$ BH-SP binding (Table 1). Finally, a putative SP antagonist [D$\mathrm{Pro}^{2}$, D-Trp ${ }^{7,9}$ SP (Rosell and Folkers, 1982) is almost inactive on ${ }^{125} \mathrm{I}-\mathrm{BH}-\mathrm{SP}$ binding sites (Table 1).

\section{Receptor autoradiography}

The distribution of SP receptor binding sites undergoes major modifications during postnatal ontogeny (Figs. 3-8). As shown in Figure 3 (sagittal sections), high densities of SP binding sites are present soon after in most brain-stem nuclei at P1-P4, while very low concentrations of sites are seen in the same regions at P21 and in adult brain. More extensive details on the distribution of SP binding sites during postnatal ontogeny are shown in a series of coronal sections from rat brain at different ages (P1-P21) (Figs. 4-8).

P1. High densities of SP binding sites are present in most nuclei of the brain stem (Fig. $3 A$ ), some midbrain areas (Fig. $3 A$ ), and the external plexiform layer of the olfactory bulb (Fig. $3 A$ ). More specifically, coronal sections show that high densities of binding sites are present in the striatum (Fig. $4, A-C$ ), olfactory tubercule (Fig. $4, A, B$ ), dentate gyrus of the hippocampus
(Fig. 4, C, D), various hypothalamic and amygdaloid nuclei (Fig. 4, $C, D$ ), habenula (Fig. $4 D$ ), amygdalohippocampal area (Fig. $4 D$ ), colliculi (Fig. 4E), and entorhinal cortex (Fig. $4 E$ ). Moderate densities of sites are seen in the lateral septum (Fig. 4, $A$, $B$ ), and various thalamus nuclei (Fig. $4 C$ ). Low densities are found in most cortical areas (Fig. 4). White matter areas such as the corpus callosum are devoid of specific binding sites (Fig. 4).

$P 4$. SP binding sites are similarly distributed 1 and $4 \mathrm{~d}$ after birth (Figs. 4, 5). Very high densities of sites are found in various brain-stem nuclei, including the central gray matter (Fig. $5 E$ ), raphe nuclei (Fig. $5 E$ ), trigeminal nerve (not shown), locus coeruleus (not shown), and inferior olive (not shown). High densities of sites are present in the striatum (Fig. 5, $A, B$ ), habenula (Fig. 5C), dentate gyrus (Fig. 5, $C, D$ ), certain thalamic nuclei (Fig. 5C), and superior colliculus (Fig. 5D). Moderate densities are found in the lateral septum (Fig. 5, $A, B$ ) and various hypothalamic nuclei (Fig. $5 C$ ). Low to moderate densities are present in most cortical areas (Fig. 5). Very low densities of sites are present in the substantia nigra throughout postnatal ontogeny (Figs. 3-8).

$P 7$. Very high densities of sites are still present over most upper and lower brain-stem nuclei (Fig. 6). As shown in Figure 6 , high densities of SP binding sites are found in the external plexiform layer of the olfactory bulb (Fig. 6A), striatum (Fig. 6, $B, C$ ), lateral septum (Fig. $6 B$ ), olfactory tubercule (Fig. $6 B$ ), dentate gyrus and hippocampus (Fig. 6, $C, D$ ), amygdala (Fig. $6, C, D$ ), habenula (Fig. $6 C$ ), anterior hypothalamic nucleus (Fig. 6C), certain thalamic nuclei (Fig. 6, $C, D$ ), superior colliculus (Fig. 6, $E, F$ ), inferior colliculus (Fig. $6 G$ ), central gray matter (Fig. $6 F$ ), entorhinal cortex (Fig. 6, $E, F$ ), medial geniculate nuclei (Fig. 6F), locus coeruleus (Fig. 6G), olive nuclei, and nucleus of the trigeminal nerve. Low densities of sites are present in cortex (Fig. 6), while only background levels are seen in the cerebellum (Fig. 6G). White matter areas are devoid of specific ${ }^{125}$ I-BH-SP binding sites (Fig. 6).

P14. Fourteen days after birth, the autoradiographic distribution of SP binding sites in rat brain is similar to the one previously reported in adult brain (Quirion et al., 1983; Shults et al., 1984), except for the high densities of sites in the brain stem (Fig. 7, $F, H$ ) and somewhat higher densities in the hypothalamus (Fig. 7, D, E). In the forebrain, high-density sites are found in various areas including the external plexiform layer of the olfactory bulb (Fig. $7 A$ ), striatum (Fig. $7, B-D$ ), olfactory tubercule (Fig. 7, $B, C$ ), lateral septum (Fig. $7 C$ ), habenula (Fig. $7, D, E)$, certain thalamic nuclei (Fig. $7, D, E$ ), amygdalohippocampal area (Fig. $7, D, E$ ), amygdala (Fig. $7, D, E$ ), zona incerta (Fig. $7 E$ ), and dentate gyrus (Fig. 7, $D, E$ ). The laminar distribution of binding sites in the hippocampus is highly apparent (Fig. 7, $D-F$ ). Low to moderate densities of sites are present, in a laminated fashion, in various cortical areas (Fig. 7). More caudally, high densities of SP sites are found in the superior colliculus (Fig. 7, $F, G$ ), central gray matter (Fig. 7, $F$, $G$ ), medial geniculate nuclei (Fig. $7, F, G$ ), pre- and parasubiculum (Fig. $7 G$ ), locus coeruleus (Fig. $7 H$ ), and other brain-stem nuclei (Fig. $7 \mathrm{H}$ and not shown). Very low densities of sites are seen in the substantia nigra (Fig. $7, F, G$ ).

$P 21$. The autoradiographic distribution of SP binding sites in 21-d-old rats is very similar to the adult one, with low densities of sites seen in most brain-stem nuclei (Figs. 3, 8). As shown in Figure 8, high densities of sites are seen in striatum (Fig. 8, $B-F$ ), olfactory tubercule (Fig. 8, $B-D$ ), septum (Fig. 8, $C, D$ ), amygdala (Fig. 8, $F, G$ ), amygdalohippocampal area (Fig. 8, $G$, $H$ ), habenula (Fig. 8, $F, G$ ), anterior hypothalamus (Fig. 8, $E$, $F$ ), dentate gyrus (Fig. 8, $F-H)$, superior colliculus (Fig. 8, $I, J$ ), central gray matter (Fig. $8 J$ ), and locus coeruleus $(8 K)$. SP binding sites are distributed in a laminar fashion in the cortex and hippocampus (Fig. 8). Very low densities of sites are seen in the 


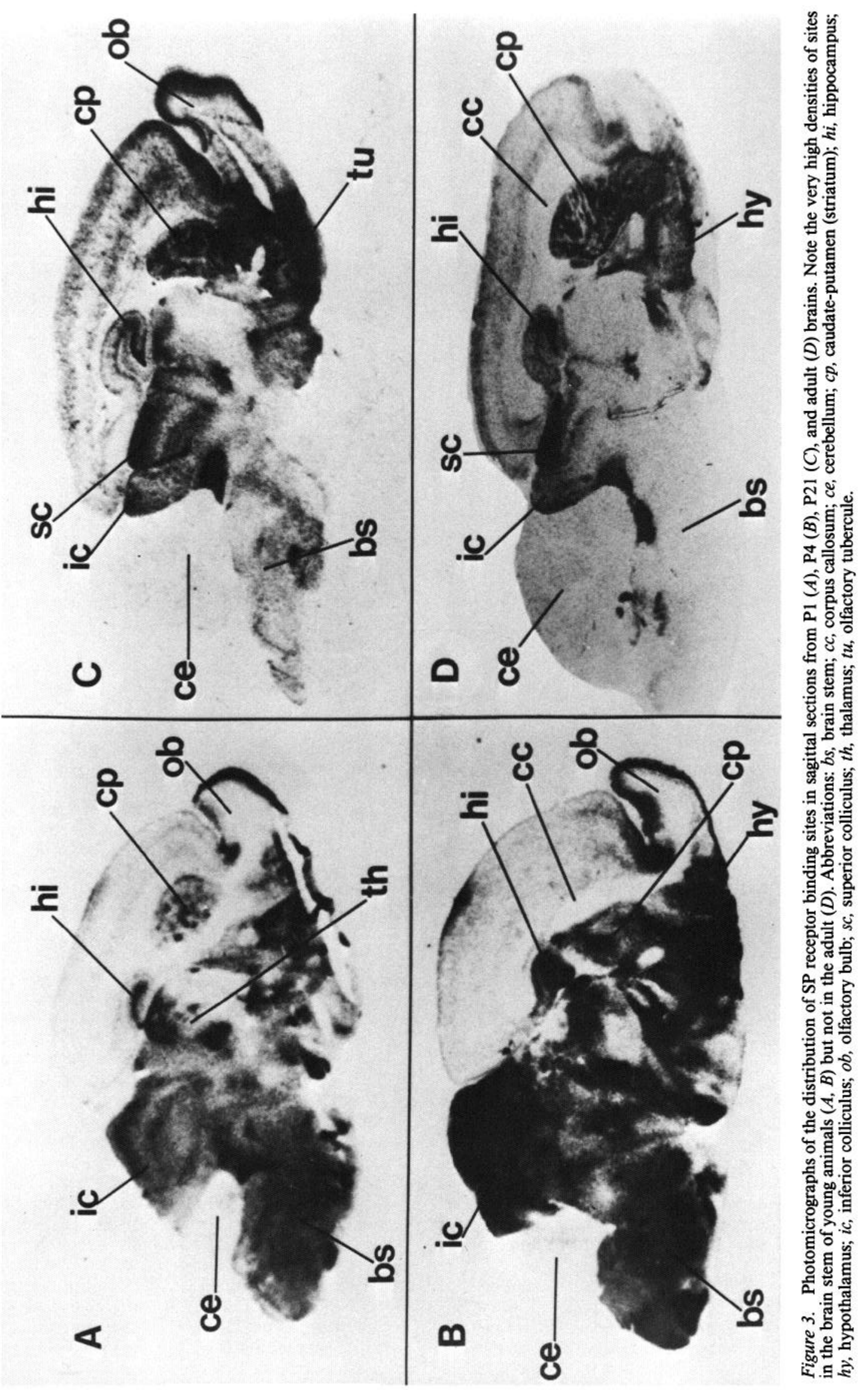




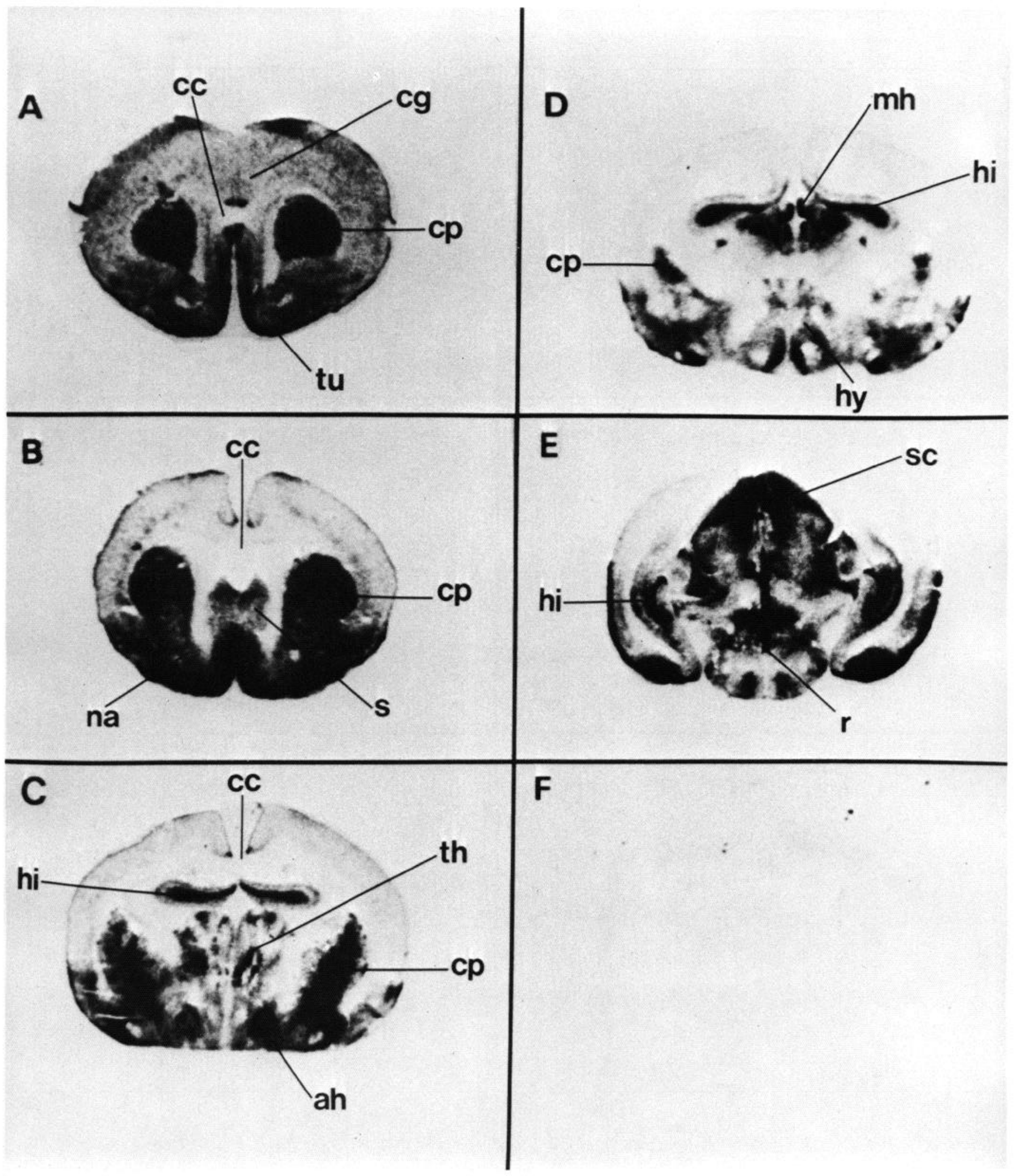

Figure 4. Photomicrographs of the distribution of SP receptor binding sites in coronal brain sections from 1-d-old rats (P1). High densities of sites are present in the striatum $(A, B)$, olfactory tubercule $(A, B)$, dentate gyrus $(C, D)$, amygdala $(C, D)$, and colliculus $(E)$. Moderate densities are found in the lateral septum $(A, B)$ and hypothalamus $(C, D)$. Section incubated in presence of $1.0 \mu \mathrm{M}$ SP $(F)$. Abbreviations: ah, anterior hypothalamus; $c c$, corpus callosum; $c g$, cingulate cortex; $c p$, caudate-putamen (striatum); $h i$, hippocampus; $h y$, hypothalamus; $m h$, medial habenula; $n a$, nucleus accumbens; $r$, raphe; $s$, septum; $s c$, superior colliculus; $t h$, thalamus; $t u$, olfactory tubercule. 


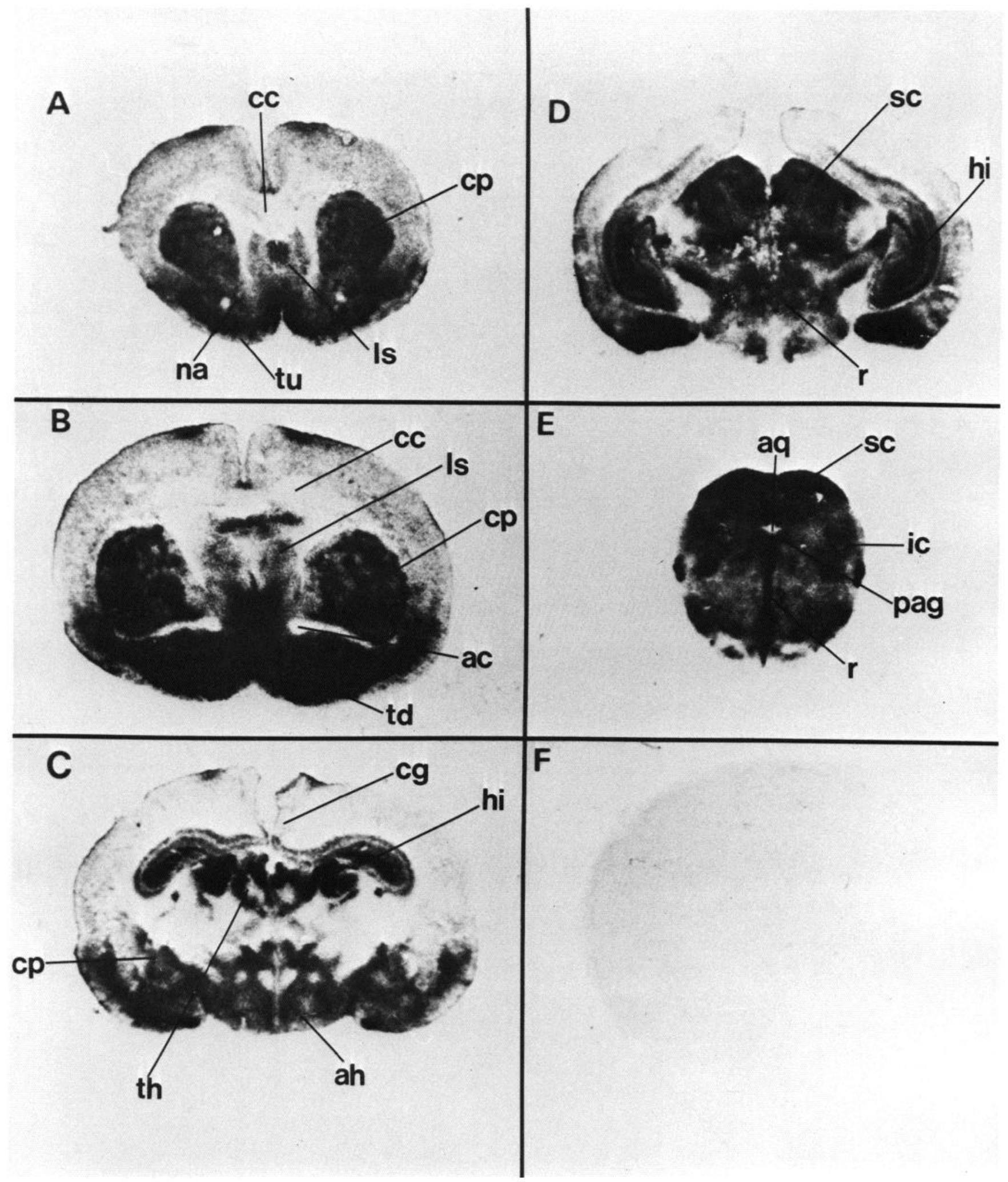

Figure 5. Photomicrographs of the distribution of SP receptor binding sites in coronal brain sections from 4-d-old rats (P4). High densities of sites are present in the striatum $(A, B)$, olfactory tubercule $(A, B)$, dentate gyrus $(C, D)$, certain thalamic nuclei $(C)$, superior colliculus $(D, E)$, and most brain-stem nuclei $(E)$. Moderate densities of sites are found in the lateral septum $(A, B)$ and the hypothalamus $(C)$. Section incubated in the presence of $1.0 \mu \mathrm{M}$ SP $(F)$. Abbreviations: $a c$, anterior commissura; $a h$, anterior hypothalamus; $a q$, cerebral aqueduct; $c c$, corpus callosum; $c g$, cingulate cortex; $c p$, caudate-putamen (striatum); $h i$, hippocampus; $i c$, inferior colliculus; $l s$, lateral septum; na, nucleus accumbens; pag, periaqueductal gray matter (central gray); $r$, raphe; $s c$, superior colliculus; $t d$, tractus diagonalis; $t h$, thalamus; $t u$, olfactory tubercule. 


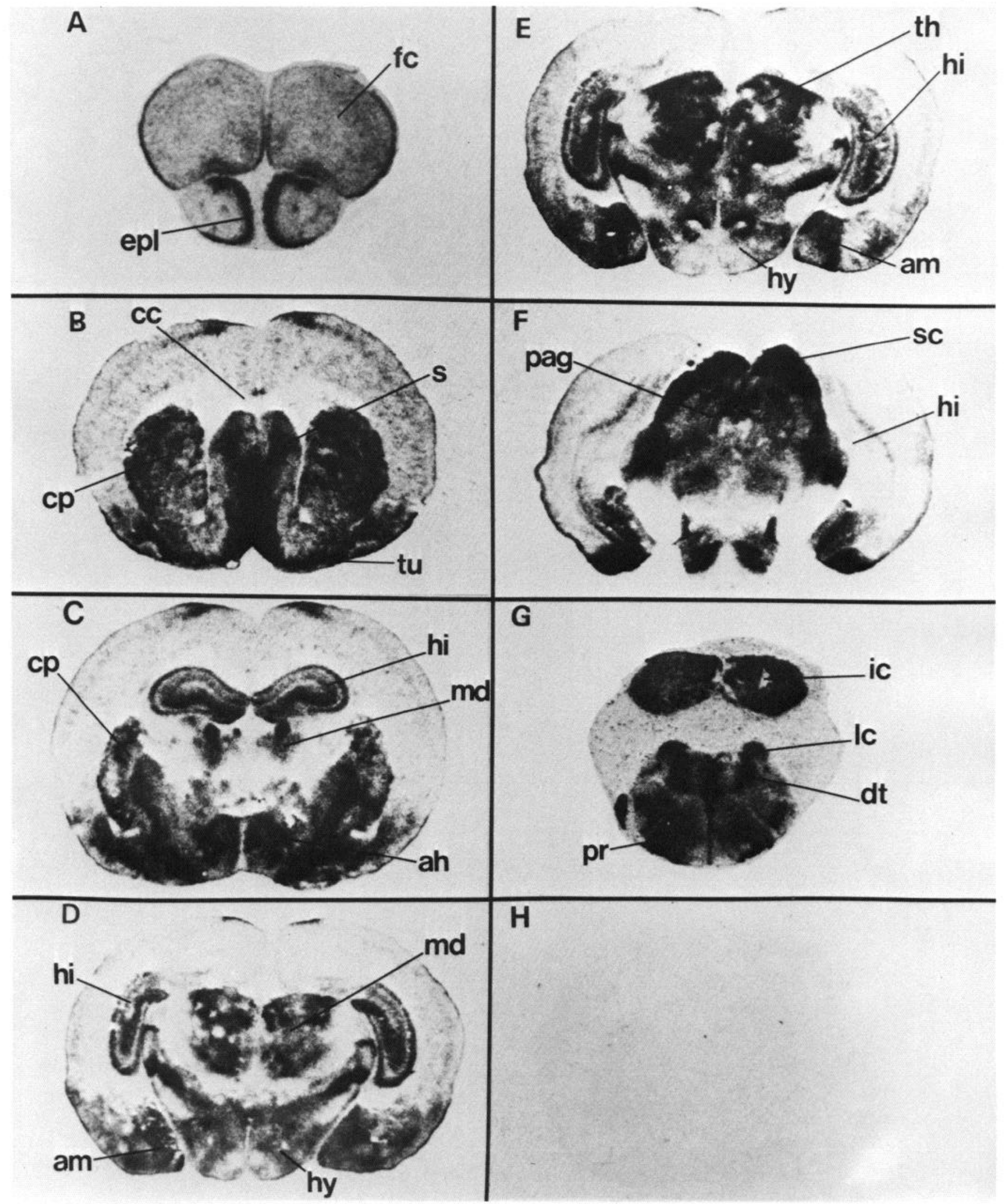

Figure 6. Photomicrographs of the distribution of SP receptor binding sites in coronal brain sections from 7-d-old rats (P7). High densities of sites are seen in the external plexiform layer of the olfactory bulb $(A)$, striatum $(B, C)$, septum $(B)$, dentate gyrus $(C-E)$, certain thalamic nuclei $(C-E)$, superior colliculus $(F)$, medial geniculate nuclei $(F)$, inferior colliculus $(G)$, and most brain-stem nuclei $(G)$ present at this level. Section incubated in the presence of $1.0 \mu \mathrm{M}$ SP $(H)$. Abbreviations: $a h$, anterior hypothalamus; $a m$, amygdala; $c c$, corpus callosum; $c p$, caudate-putamen (striatum); $d t$, dorsal tegmentum; epl, external plexiform layer of the olfactory bulb; $f c$, frontal cortex; $h i$, hippocampus; $h y$, hypothalamus; $i c$, inferior colliculus; $l c$, locus coeruleus; $m d$, mediodorsal thalamic nuclei; $s$, septum; $s c$, superior colliculus; $t h$, thalamus; $t u$, olfactory tubercule. 


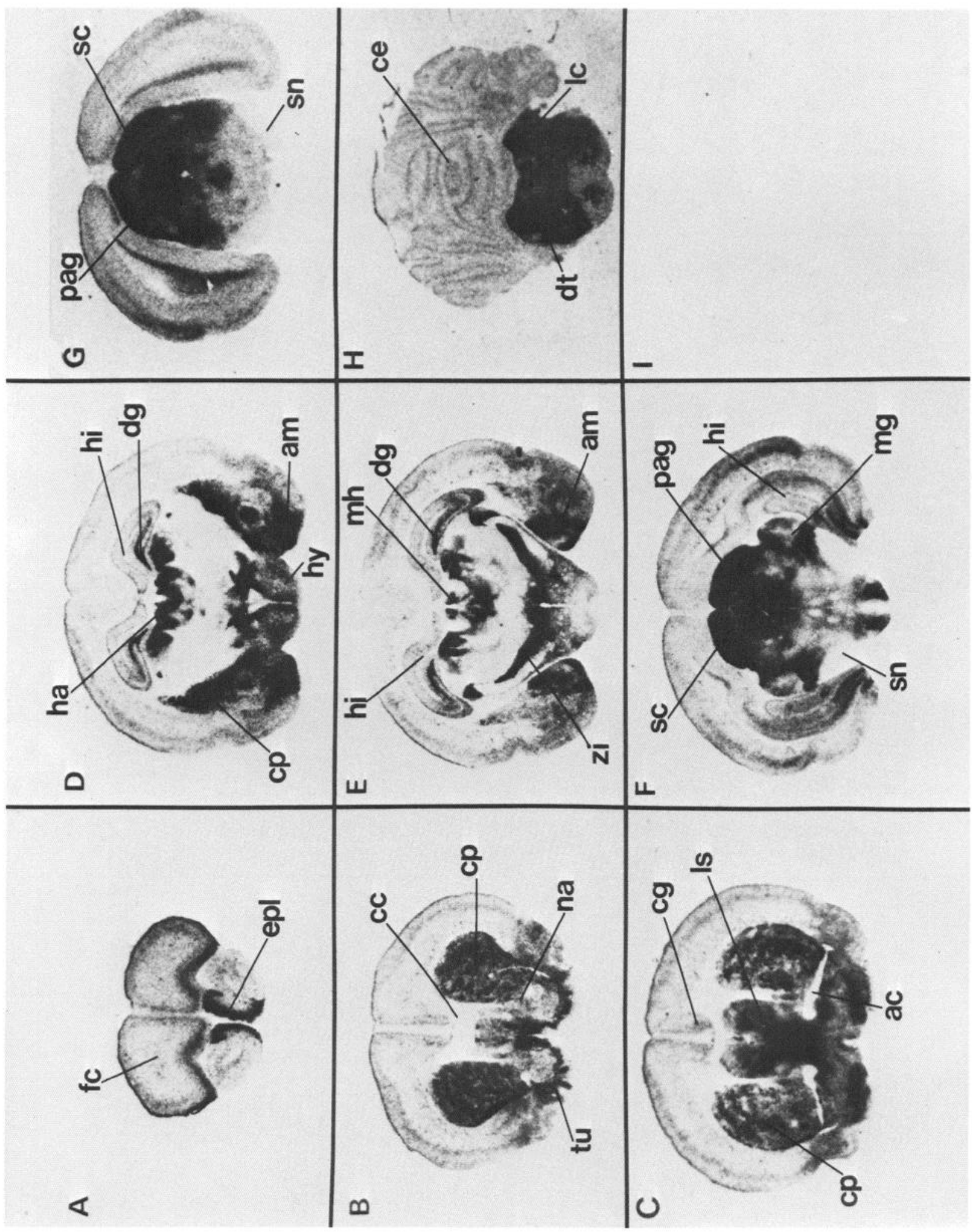

Figure 7. Photomicrographs of the distribution of SP receptor binding sites in coronal brain sections from 14-d-old rats (P14). High densities of sites are found in the external plexiform layer of the olfactory bulb $(A)$, olfactory tubercule $(B, C)$, striatum $(B-D)$, septum $(C)$, habenular nuclei $(D, E)$, dentate gyrus $(D, E)$, amygdalohippocampal area $(D, E)$, certain hypothalamic nuclei $(D, E)$, superior colliculus $(F, G)$, central gray matter $(F, G)$, and most brain-stem nuclei, including the locus coeruleus $(H)$. Moderate densities are seen in the hippocampus $(D-F)$ and pre- and 


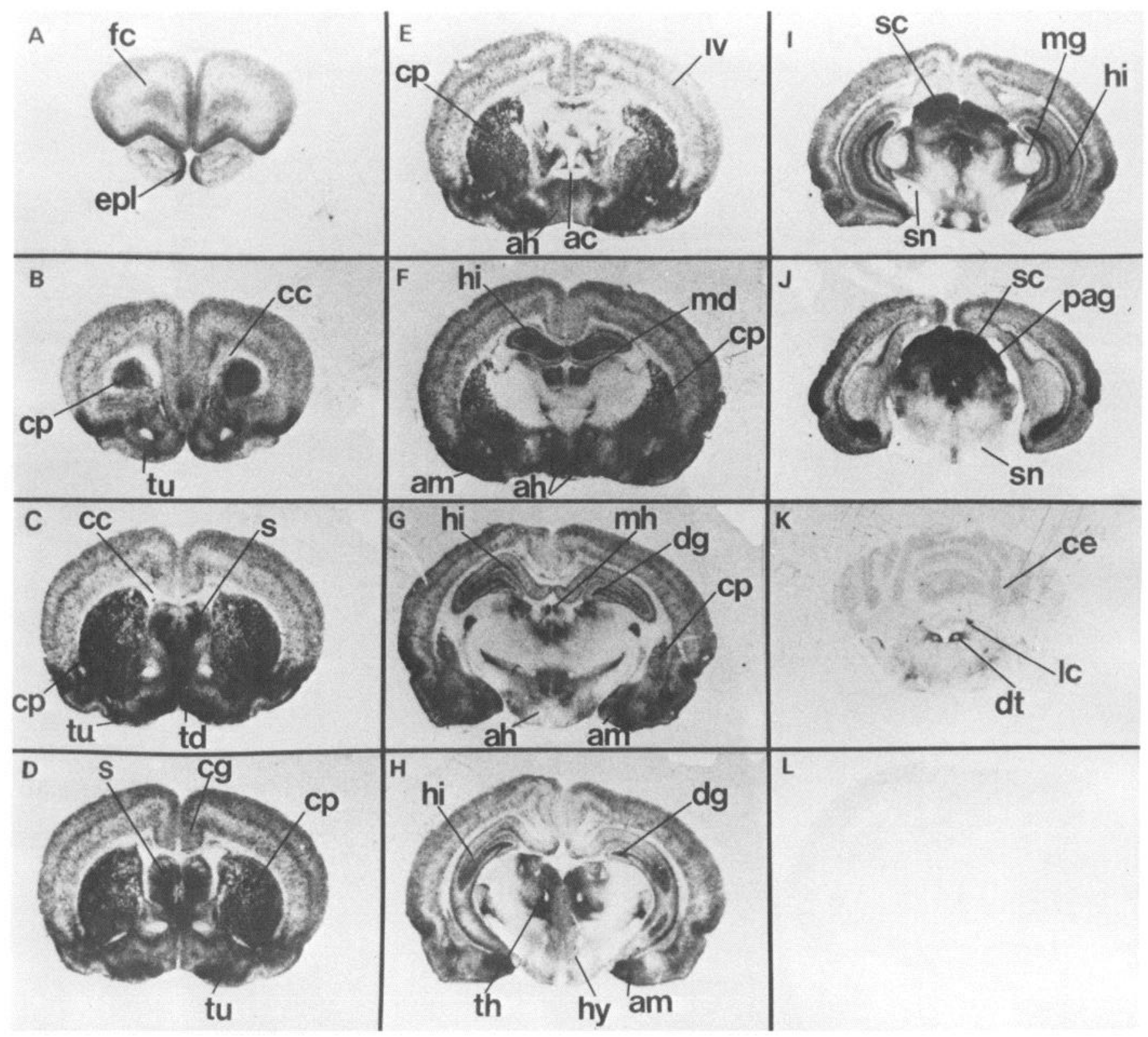

Figure 8. Photomicrographs of the distribution of SP receptor binding sites in coronal brain sections from 21-d-old rats (P21). High densities of sites are found in various regions, including the external plexiform layer of the olfactory bulb $(A)$, striatum $(B, F)$, lateral septum $(C, D)$, olfactory tubercule $(C, D)$, habenula $(F, G)$, hypothalamus $(E-G)$, dentate gyrus $(F, I)$, certain thalamic nuclei $(G, H)$, amygdalohippocampal area $(G, H)$, superior colliculus $(I, J)$, central gray matter $(J)$, and locus coeruleus $(K)$. At this age, very few brain-stem nuclei contain high densities of SP binding sites $(K)$. The substantia nigra is virtually devoid of SP binding sites $(I, J)$. Sections incubated in the presence of $1.0 \mu \mathrm{M}$ SP $(L)$. Abbreviations: $a c$, anterior commissura; $a h$, anterior hypothalamus; $a m$, amygdala; $c c$, corpus callosum; $c e$, cerebellum; $c g$, cingulate cortex; $c p$, caudate-putamen (striatum); $d g$, dentate gyrus; $d t$, dorsal tegmentum; epl, external plexiform layer of the olfactory bulb; $f c$, frontal cortex; $h i$, hippocampus; $h y$, hypothalamus; $l c$, locus coeruleus; $m d$, medial thalamic nuclei; $m g$, medial geniculate nucleus; $m h$, medial habenula; pag, periaqueductal gray matter (central gray); $s$, septum; $s c$, superior colliculus; $s n$, substantia nigra; $t d$, tractus diagonalis; $t h$, thalamus; $t u$, olfactory tubercule; $i v$, fourth layer of the cortex.

parasubiculum $(G)$. Very low densities are present in the substantia nigra $(F, G)$. Section incubated in presence of $1.0 \mu \mathrm{M}$ SP $(I)$. Abbreviations: $a c$, anterior commissura; $a m$, amygdala; $c c$, corpus callosum; $c e$, cerebellum; $c g$, cingulate cortex; $c p$, caudate-putamen (striatum); $d g$, dentate gyrus; $d t$, dorsal tegmentum; epl, external plexiform layer of the olfactory bulb; $f c$, frontal cortex; $h a$, habenula; $h i$, hippocampus; $h y$, hypothalamus; $l c$, locus coeruleus; $l s$, lateral septum; $m h$, medial habenula; $m g$, medial geniculate nucleus; $n a$, nucleus accumbens; pag, periaqueductal gray matter (central gray); $s c$, superior colliculus; $s n$, substantia nigra; $t u$, olfactory tubercule; $z i$, zona incerta. 


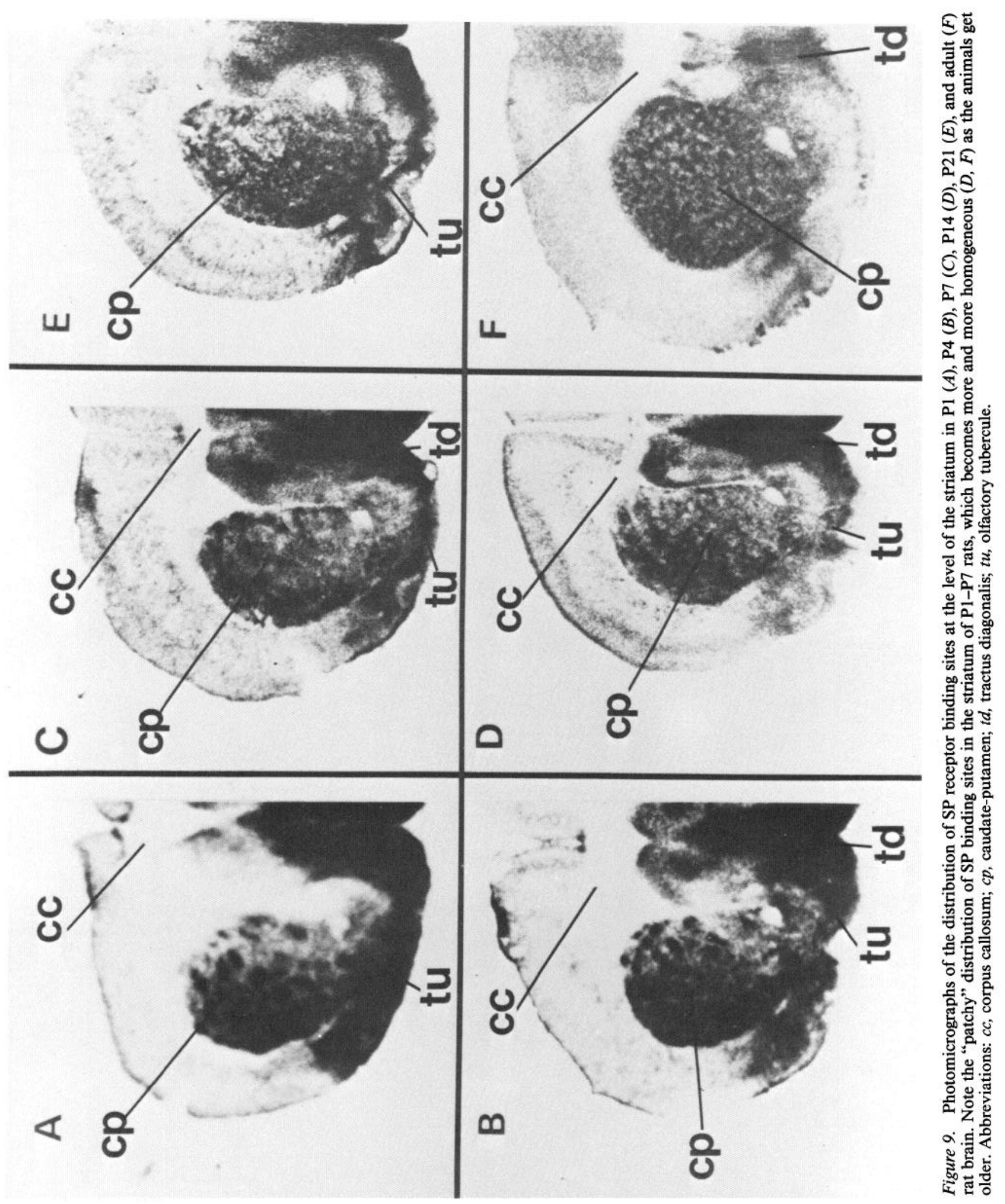


substantia nigra (Fig. $8, I, J$ ), and white matter areas such as the corpus callosum are devoid of binding sites (Fig. 8).

\section{Distribution of SP binding sites in the striatum during ontogeny}

Besides the marked differences in SP binding sites seen in the brain stem during ontogeny, an interesting reorganization of the distribution of SP sites is found in the striatum (Fig. 9). Early postnatally (P1-P7), SP binding sites are distributed in "patches" in the striatum (Fig. 9, $A-C$ ), while the distribution is more and more diffuse as the animals get older (Fig. 9, D-F). At P1, P4, and $\mathrm{P} 7$, the SP binding sites in the striatum show a characteristic patchy distribution (Figs. $3 A, 9$ ), while this is certainly not the case in the adult striatum (Fig. $3 D, 9 F$ ).

\section{Discussion}

It is well known that important morphological changes take place during ontogeny, and the study of the development of neuropeptides and their receptors could help to determine the possible roles of a given peptide in the developmental process. Our results clearly show that major modifications in the distribution of SP receptor densities occur during ontogeny. Similar results have been reported for other neuropeptide receptors such as opiates (Kent et al., 1982; Unnerstall et al., 1983) and neurotensin (Goedert et al., 1985).

Since the density of ${ }^{125} \mathrm{I}-\mathrm{BH}-\mathrm{SP}$ binding sites varied markedly during ontogeny, it was important to determine if these sites had similar structural requirements throughout development. We observed a very similar ligand selectivity pattern for ${ }^{125}$-IBH-SP binding sites during ontogeny. As reported before for rat adult brain (Mantyh et al., 1984a; Mohini et al., 1985; Quirion et al., 1983; Shults et al., 1984; Torrens et al., 1983; Wolf et al., 1985), SP fragments were only weak inhibitors of ${ }^{125} \mathrm{I}$ BH-SP binding during ontogeny, while SP itself and physalaemin were the most potent. Other tachykinins such as substance $\mathrm{K}$, neuromedin $\mathrm{K}$, kassinin, and eledoisin were very weak competitors for ${ }^{125}$ I-BH-SP binding sites, suggesting that these neuropeptides are probably acting on other classes of tachykinin receptors (Beaujouan et al., 1984; Buck et al., 1984; Cascieri and Liang, 1984; Kalivas et al., 1985; Mantyh et al., 1984b; Quirion, 1985; Quirion and Dam, 1985a). A putative SP receptor antagonist [D-Pro ${ }^{2}$, D-Trp $\left.{ }^{7,9}\right]$ SP (Rosell and Folkers, 1982) was almost inactive on these sites, as in the case of adult brain tissue (Quirion et al., 1983). These data demonstrate that ${ }^{125} \mathrm{I}-$ BH-SP binding sites have similar structural requirements throughout brain development. Naturally, the possible binding of ${ }^{125} \mathrm{I}-\mathrm{BH}-\mathrm{SP}$ to non-neuronal elements during ontogeny cannot be excluded. However, the very similar ligand selectivity pattern obscrved during ontogeny suggests that most of the ${ }^{125}$ I-BH-SP binding is to receptor-relevant (neuronal) structures.

It is very likely that SP binding sites appear very early during embryogenic development, since significant densities of sites are present in rat brain $3 \mathrm{~d}$ before birth (E18). Moreover, the density of SP receptors markedly increases $1 \mathrm{~d}$ before birth, suggesting that SP might be a very important factor in the early maturation and organization of the CNS. The number of SP receptors subsequently decreases to reach more or less adult levels during the second week after birth. However, autoradiographic data clearly demonstrate that even if the total number of SP binding sites does not change much from P7 to adulthood, the distribution of these sites undergoes major modifications.

This is especially striking in the upper and lower brain stem, which contain very high densities of sites up to $14 \mathrm{~d}$ after birth but not later. This could indicate that SP and/or related tachykinins may have an important role during the developmental organization of these brain regions. This is of special interest since it has been shown that SP acts as a "growth factor" in certain brain-stem nuclei following various pharmacological manipulations (Jonsson and Hallman, 1982a, b, 1983a, b). For example, Jonsson and Hallman (1982a, b) have shown that SP either prevents the degeneration of damaged noradrenergic neurons or has a regrowth stimulatory action on brain-stem noradrenergic cell bodies during ontogeny. This indicates that SP may have a growth-stimulatory effect on locus coeruleus neurons during neonatal development (Jonsson and Hallman, 1983b). It has also been shown that SP has similar actions on damaged brain-stem serotonergic neurons during ontogeny (Jonsson and Hallman, 1983a). Moreover, other groups have reported that SP stimulates neurite outgrowth in embryonic chick dorsal root ganglia (Narumi and Fujita, 1978), increases neurite extension in neuroblastoma cells (Narumi and Maki, 1978), and accelerates the regeneration of central catecholaminergic fibers in rat occipital cortex by acting on noradrenergic cells in the locus coeruleus (Nakai and Kasamatsu, 1984). Finally, Nilsson et al. (1985) recently showed that SP and the newly discovered tachykinin, substance $\mathrm{K}$, stimulate cell growth in connective tissues. Thus, this strongly suggests that SP and other mammalian tachykinins may have important roles as tropic factors in certain areas of the nervous system (e.g., brain stem), especially during ontogeny.

The very early appearance of SP-like immunoreactivity during embryogenic development also suggests that SP could be an important factor involved in the maturation of various brain pathways. It has been shown that SP is present in the rat brain fetus at gestational day 14 , reaching adult levels between days 5 and 15 after birth (Inagaki et al., 1982; Sakanaka et al., 1982). Similar data have been obtained in fetal human brain, with high densities of SP-like fibers identified throughout the lower brain stem (Charnay et al., 1983; Del Fiacco et al., 1984; Namura et al., 1982). Interestingly, it has been shown that in various brain areas, especially in the brain stem, more numerous SP-like cell bodies are detected in neonatal than in adult brain (Del Fiacco et al., 1984; Inagaki et al., 1982; Sakanaka et al., 1982). This correlates well with the high density of SP binding sites present in the brain stem of neonatal animals.

Overall, the ontogeny of SP receptor binding sites appears to precede the full development of the SP neuronal network in rat brain. Our data indicate that the organization of the distribution of SP receptors is completed by 7-14 d after birth, while at least an additional week is needed for the maturation of the various SP pathways (Inagaki et al., 1982; Sakanaka et al., 1982). Similar results have been reported for the cholinergic (Coyle and Yamamura, 1976) and opioid (Kent et al., 1982; Patey et al., 1980) systems, suggesting that receptor binding sites appear during ontogeny before markers for the appropriate presynaptic elements. One important exception to this phenomenon is seen in the substantia nigra. Whilc SP-like fiber terminals are present in this structure from gestational day 19 (Inagaki et al., 1982; Sakanaka et al., 1982), it is not possible to detect appreciable densities of SP binding sites in the substantia nigra during developmental ontogeny. Already, various groups have reported on the discrepancy between the distribution of SP and its receptors in the striatonigral pathway (Mantyh et al., 1984a; Quirion et al., 1983; Rothman et al., 1984; Shults et al., 1984). Recent data strongly suggest that this apparent discrepancy could be related to the presence of the newly discovered tachykinin, substance $\mathrm{K}$, and substance $\mathrm{K}$ receptors in the substantia nigra (Kalivas et al., 1985; Mantyh et al., 1984b; Quirion, 1985; Quirion and Dam, 1985a). Thus, it would be of interest to compare the respective ontogeny of the various tachykinin receptors in mammalian brain.

The redistribution of striatal SP receptor binding sites during postnatal ontogeny is also of interest. Our autoradiographic data show that in neonatal rat brain, SP binding sites have a "patchy" distribution in the caudate-putamen, while this is not the case in the adult striatum. A similar situation has previously been 
observed for muscarinic receptors (Nastuk and Graybiel, 1985; Rotter et al., 1979) and acetylcholinesterase staining (Graybiel and Ragsdale, 1978, 1983; Graybiel et al., 1981a, b), while the opposite is true for mu opioid receptors (Kent et al., 1982). It is well known that in the mammalian striatum, these patches or striosomes correspond to acetylcholinesterase-poor areas and dopamine terminal-enriched islands (Graybiel and Ragsdale, 1978, 1983). The functional significance of this architectural organization is unknown. However, Gerfen (1984) has recently shown that the striosomes receive inputs from the prelimbic cortex and project to the substantia nigra, pars compacta. Our findings suggest that SP receptors and dopamine-containing striatal afferents could be closely associated during ontogeny but probably not as much in adulthood.

In summary, SP binding sites appear early on during brain development. A major increase in SP recepturs is observed $1 \mathrm{~d}$ before birth, suggesting that SP may participate in the early architectural development of the CNS. Postnatally, SP receptors undergo major redistribution in rat brain, with high densities of sites present in the brain stem of neonatal but not adult animals. This suggests that SP and/or related tachykinins may act as an important growth factor during the ontogenetic development of the brain.

\section{References}

Beaujouan, J. C., Y. Torrens, A. Viger, and J. Glowinski (1984) A new type of tachykinin binding site in the rat brain characterized by specific binding of a labelled eledoisin derivative. Mol. Pharmacol. 26: $248-254$.

Brownstein, M. J., E. A. Mroz, J. S. Kizer, M. Palkovits, and S. E. Leeman (1976) Regional distribution of substance $P$ in the brain of the rat. Brain Res. 116: 299-305.

Buck, S. H., I. Burcher, C. W. Shults, W. Lovenberg, and T. L. O'Donohue (1984) Novel pharmacology of substance $\mathrm{K}$ binding sites: A third type of tachykinin receptor. Science 226: 987-989.

Cascieri, M. A., and T. Liang (1984) Binding of [ $\left.{ }^{125} \mathrm{I}\right]$ Bolton-Hunter conjugated eledoisin to rat brain cortex membranes. Evidence for two classes of tachykinin receptors in the mammalian central nervous system. Life Sci. 35: 179-184.

Chang, M. M., and S. E. Leeman (1970) Isolation of a sialogogic peptide from bovine hypothalamic tissue and its characterization as substance P. J. Biol. Chem. 245: 4784-4790.

Charlton, C. G., and C. J. Helke (1985) Autoradiographic localization and characterization of spinal cord substance $P$ binding sites: High densities in sensory, autonomic, and Onuf's motor nuclei. J. Neurosci. 5: 1653-1661.

Charnay, Y., C. Paulin, J. A. Chayvialle, and P. M. Dubois (1983) Distribution of substance P-like immunoreactivity in the spinal cord and dorsal root ganglia of the human and infant. Neuroscience 10: 41-55.

Coyle, J. T., and H. Yamamura (1976) Neurochemical aspects of the ontogenesis of cholinergic neurons in the rat brain. Brain Res. 118: 429-440.

Cuello, A. C., and I. Kanazawa (1978) The distribution of substance P immunoreactive fibers in the rat central nervous system. J. Comp. Neurol. 178: 129-156.

Del Fiacco, M., M. L. Dessi, and M. C. Leranti (1984) Topographical localization of substance $P$ in the human post-mortem brainstem. An immunohistochemical study in the newborn and adult tissue. Neuroscience 12: 591-611.

Erspamer, V. (1981) The tachykinin peptide family. Trends Neurosci. 4: $267-269$

Gerfen, C. R. (1984) The neostriatal mosaic: Compartmentalization of corticostriatal input and striato-nigral output systems. Nature 311 : 461-464.

Goedert, M., S. P. Hunt, P. W. Mantyh, and P. C. Emson (1985) The ontogenetic development of ncurotensin-like immunoreactivity and neurotensin receptors in the cat striatum. Dev. Brain Res. 20:127131.

Graybiel, A. M., and C. W. Ragsdale (1978) Histochemically distinct compartments in the striatum of human, monkey and cat demon- strated by acetylthiocholinesterase stain. Proc. Natl. Acad. Sci. USA 75: 5723-5726.

Graybiel, A. M., and C. W. Ragsdale (1983) Biochemical anatomy of the striatum. In Chemical Neuroanatomy, P. C. Emson, ed., pp. 427504.

Graybiel, A. M., V. M. Pickel, T. H. Joh, D. J. Reis, and C. W. Ragsdale (1981a) Direct demonstration of a correspondence between the dopamine islands and acetylcholinesterase patches in the developing striatum. Proc. Natl. Acad. Sci. USA 78: 5871-5875.

Graybiel, A. M., C. W. Ragsdale, E. S. Yoneoka, and R. P. Elde (1981b) An immunohistochemical study of enkephalins and other neuropeptides in the striatum of the cat with evidence that the opiate peptides are arranged to form mosaic patterns in register with the striosomal compartments visible by acetylcholinesterase staining. Neuroscience 6: 377-397.

Helke, C. J., C. W. Shults, T. N. Chase, and T. L. O'Donohue (1984) Autoradiographic localization of substance $P$ receptors in rat medulla: Effect of vagotomy and nodose ganglionectomy. Neuroscience 12: 215-223.

Henry, J. L. (1976) Effects of substance P on functionally identified units in cat spinal cord. Brain Res. 114: 439-451.

Herkenham, M., and C. B. Pert (1982) Light microscopic localization of brain opiate receptors: A general autoradiographic method which preserves tissue quality. J. Neurosci. 2: 1129-1149.

Hylden, J. L. K., and G. L. Wilcox (1981) Intrathecal substance P elicits a caudally-directed biting and scratching behavior in mice. Brain Res. 217: 212-215.

Inagaki, S., M. Sakanaka, S. Shiosaka, E. Senba, K. Takatsuki, H. Takagi, Y. Kawai, H. Minagawa, and M. Tohyama (1982) Ontogeny of substance P-containing neuron system of the rat: Immunohistochemical analysis. I. Forebrain and upper brain stem. Neuroscience 7:251277.

Jonsson, G., and H. Hallman (1982a) Substance P counteracts neurotoxin damage on norepinephrine neurons in rat brain during ontogeny. Science 215: 75-77.

Jonsson, G., and H. Hallman (1982b) Substance P modifies the 6-hydroxydopamine induced alteration of postnatal development of central noradrenaline neurons. Neuroscience 7: 2909-2918.

Jonsson, G., and H. Hallman (1983a) Effect of substance $P$ on the 5,7-dihydroxytryptamine induced alteration of postnatal development of central serotonin neurons. Med. Biol. 61: 105-112.

Jonsson, G., and H. Hallman (1983b) Effect of substance P on neonatally axotomized noradrenaline neurons in rat brain. Med. Biol. 61: 179-185.

Kalivas, P. W., A. Y. Deutch, J. E. Maggio, P. W. Mantyh, and R. H. Roth (1985) Substance $K$ and substance $P$ in the ventral tegmental area. Neurosci. Lett. 57: 241-246.

Kent, J. L., C. B. Pert, and M. Herkenham (1982) Ontogeny of opiate receptors in rat forebrain: Visualization by in vitro autoradiography. Dev. Brain Res. 2: 487-504.

Kessler, J. A., and I. B. Black (1981) Nerve growth factor stimulates development of substance $\mathrm{P}$ in the embryonic spinal cord. Brain Res. 208: 135-145.

Ljungdahl, A., T. Hökfelt, and G. Nilsson (1978) Distribution of substance $P$ like immunoreactivity in the central nervous system of the rat. I. Cell bodies and nerve terminals. Neuroscience 3: 861-943.

Lowry, O., M. Rosenbrough, A. Farr, and R. Randall (1951) Protein measurement with folin reagent. J. Biol. Chem. 193: 265-275.

Mantyh, P. W., S. P. Hunt, and J. E. Maggio (1984a) Substance P receptors: Localization by light microscopic autoradiography in rat brain using [ $\left.{ }^{3} \mathrm{H}\right] \mathrm{SP}$ as the radioligand. Brain Res. 307: 147-165.

Mantyh, P. W., J. E. Maggio, and S. P. Hunt (1984b) The autoradiographic distribution of kassinin and substance $\mathrm{K}$ binding sites is different from the distribution of substance $P$ binding sites in rat brain. Eur. J. Pharmacol. 102: 361-364.

McGregor, G. P., P. L. Woodhams, D. J. O'Shaughnessy, M. A. Ghatei, J. M. Polak, and S. R. Bloom (1982) Developmental changes in bombesin, substance $P$, somatostatin and vasoactive intestinal polypeptide in the rat brain. Neurosci. Lett. 28: 21-27.

Mohini, P., S. W. Bahouth, D. E.Brundish, and J. M. Musacchio (1985) Specific labeling of rat brain substance $P$ receptor with $\left[{ }^{3} \mathrm{H}\right]$ physalaemin. J. Neurosci. 5: 2078-2085.

Nakai, K., and T. Kasamatsu (1984) Accelerated regeneration of central catecholamine fibers in cat occipital cortex: Effects of substance P. Brain Res. 323: 374-379. 
Namura, H., S. Shiosaka, S. Inagaki, I. Ishimoto, E. Senba, M. Sakanaka, K. Takatsuki, T. Matyuzaki, Y. Kubota, H. Saito, S. Takase, K. Kogore, and M. Tohyama (1982) Distribution of substance P-like immunoreactivity in the lower brainstem of the human fetus: An immunohistochemical study. Brain Res. 252: 315-325.

Narumi, S., and T. Fujita (1978) Stimulatory effects of substance $\mathbf{P}$ and nerve growth factor (NGF) on neurite outgrowth in embryonic chick dorsal root ganglia. Neuropharmacology 17: 73-76.

Narumi, S., and Y. Maki (1978) Stimulatory effects of substance P on neurite extension and cyclic AMP levels in cultured neuroblastoma cells. J. Neurochem. 30: 1321-1326.

Nastuk, M. A., and A. M. Graybiel (1985) Autoradiography of $\mathbf{M}_{1}$ and $\mathbf{M}_{2}$ muscarinic binding in the striatum. In Subtypes in Muscarinic Receptors: The Second International Symposium, Abstr. 41.

Nilsson, J., A. M. von Euler, and C. J. Dalsgaard (1985) Stimulation of connective tissue cell growth by substance $P$ and substance $K$. Nature 315: 61-63.

Otsuka, M., and S. Konishi (1983) Substance P-the first peptide neurotransmitter? Trends Neurosci. $6: 317-320$.

Patey, G., S. De laBaume, C. Gros, and J. C. Schwartz (1980) Ontogenesis of enkephalinergic systems in rat brain: Post-natal changes in enkephalin levels, receptors and degrading enzyme activities. Life Sci. 27: 245-252.

Paulin, C., Y. Charnay, P. M. Dubois, and J. A. Chayvialle (1980) Localisation de substance $P$ dans le systeme nerveux du foetus humain: Résultats préliminaires. C. R. Acad. Sci. (Paris) 29: 253-260.

Pernow, B. (1983) Substance P. Pharmacol. Rev. 35: 85-141.

Quirion, K. (1985) Multiple tachykinin receptors. Trends Neurosci. 8: $183-185$.

Quirion, R., and T. V. Dam (1985a) Multiple tachykinin receptors in guinea pig brain. High densities of substance $K$ (neurokinin A) binding sites in the substantia nigra. Neuropeptides 6: 191-204.

Quirion, R., and T. V. Dam (1985b) Multiple tachykinin and substance $P$ receptors. In Substance P: Metabolism and Biological ACtions, C. C. Jordan and P. Oehme, eds., pp. 45-64, Taylor and Francis, London.

Quirion, R., R. P. Hammer, Jr., M. Herkenham, and C. B. Pert (1981) Phencyclidine (angel dust) $/ \sigma$ "opiate" receptor visualization by tritium sensitive film. Proc. Natl. Acad. Sci. USA 78: 5881-5885.
Quirion, R., C. W. Shults, T. W. Moody, C. B. Pert, T. N. Chase, and T. L. O'Donohue (1983) Autoradiographic distribution of substance $P$ receptors in rat central nervous system. Nature 303: 714-716.

Rosell, S., and K. Folkers (1982) Substance P antagonists: A new type of pharmacological tool. Trends Pharmacol. Sci. 3: 211-212.

Rothman, R. B., M. Herkenham, C. B. Pert, T. Liang, and M. A. Cascieri (1984) Visualization of rat brain receptors for the neuropeptide, substance P. Brain Res. 309: 47-54.

Rotter, A., P. M. Field, and G. Raisman (1979) Muscarinic receptors in the central nervous system of the rat. III. Postnatal development of binding of $\left[{ }^{3} \mathrm{H}\right]$ propylbenzilycholine mustard. Brain Res. Rev. 1 : 185-205.

Sakanaka, M., S. Inagaki, S. Shiosaka, E. Senba, H. Takagi, K. Takatsuki, Y. Kawai, H. Lida, Y. Hara, and M. Tohyama (1982) Ontogeny of substance P-containing neuron system of the rat: Immunohistochemical analysis. II. Lower brain stem. Neuroscience 7: 10971126.

Shults, C. W., R. Quirion, B. Chronwall, T. N. Chase, and T. L. O'Donohue (1984) A comparison of substance $P$ and substance $P$ receptors in the rat central nervous system. Peptides 5: 1097-1128.

Torrens, Y., J. C. Beaujouan, A. Viger, and J. Glowinski (1983) Properties of a ${ }^{125} I$-substance $P$ derivative binding to synaptosomes from various brain structures and the spinal cord of the rat. Naunyn Schmiedebergs Arch. Pharmacol. 324: 134-139.

Unnerstall, J. R., M. J. Kuhar, D. L. Niehoff, and J. M. Palacios (1981) Benzodiazepine receptors may be coupled to a subpopulation of GABA receptors: Evidence from a quantitative autoradiographic study. J. Pharmacol. Exp. Ther. 218: 797-804.

Unnerstall, J. R., M. E. Molliver, M. J. Kuhar, and J. M. Palacios (1983) Ontogeny of opiate binding sites in the hippocampus, olfactory bulb and other regions of the rat forebrain by autoradiographic methods. Dev. Brain Res. 7: 157-169.

Von Euler, U.S., and J. H. Gaddum (1931) An unidentified depressor substance in certain tissue extracts. J. Physiol. (Lond.) 72: 74-87.

Wolf, S. S., T. W. Moody, R. Quirion, and T. L. O'Donohue (1985) Biochemical characterization and autoradiographic localization of central substance $P$ receptors using [ $\left.{ }^{[25} I\right]$ physalaemin. Brain Res. 332: 299-307. 